\title{
CARACTERÍSTICAS DO LEITE CRU E DO QUEIJO MINAS ARTESANAL DO SERRO EM DIFERENTES MESES
}

(Characteristics of raw milk and artisanal cheese produced in Serro, Minas Gerais State, Brazil, in different months)

Silvania Pereira Figueiredo*, Cleube Andrade Boari, Paulo de Souza Costa Sobrinho, Ana Carolina Sampaio Dória Chaves, Rafael Bolina da Silva, Helenita Bárbara Fonseca Silva Correio

*Correspondência: silfigueiredo.zoo@hotmail.com

RESUMO: Objetivou-se avaliar características do leite cru e do queijo Minas artesanal do Serro, Minas Gerais, produzidos em diferentes meses. Amostras foram coletadas em janeiro, março, maio, julho, setembro e novembro de 2013. No leite cru foi determinada a acidez titulável, densidade, gordura, umidade, massa seca, proteína, lactose, resíduo mineral fixo, coliformes totais e termotolerantes, Staphylococcus spp., Staphylococcus coagulase positiva, bactérias láticas e microorganismos aeróbios mesófilos. Nos queijos foram realizadas as análises mencionadas, exceto densidade e lactose. Também foi determinado $\mathrm{pH}$, atividade de água, firmeza, adesividade e cor ( $L^{*} a^{*} b^{*}$, croma e matiz). Houve variação $(\mathrm{P}<0,05)$ na acidez, lactose, contagens de coliformes termotolerantes e bactérias láticas no leite cru. Dentre estas, ressalta-se a maior acidez e menor teor de lactose em janeiro, março, julho, setembro e novembro, meses que também apresentaram maiores contagens de coliformes termotolerantes e bactérias láticas. Nos queijos houve variação, ao longo dos meses, para $\mathrm{pH}$, acidez, gordura corrigida para a massa seca, massa seca, firmeza, adesividade, intensidade de verde $\left(-a^{*}\right)$, intensidade de amarelo $\left(b^{*}\right)$, croma $(C)$, atividade de água, contagens de coliformes termotolerantes e Staphylococcus spp. Os resultados sugerem que o teor umidade, massa seca e gordura corrigida para massa seca dos queijos são suscetíveis à umidade relativa do ar e variações nestes parâmetros influenciam a firmeza, adesividade, atividade de água e cor. Assim como no leite, nos queijos foram observadas maiores contagens de coliformes termotolerantes e de Staphylococcus spp. em janeiro e novembro, os quais apresentam maior índice pluviométrico e temperatura mais alta.

Palavras-chave: cor; físico-química; microbiologia; sazonalidade; textura

\begin{abstract}
The aim of this research was to evaluate the characteristics of raw milk and artisanal cheese produced in Serro, Minas Gerais, Brazil, in different months. Samples were collected in January, March, May, July, September and November of 2013. Titratable acidity, density, fat, moisture, dry matter, protein, lactose, ash, total and thermotolerant coliforms, Staphylococcus spp., Staphylococcus coagulase positive, lactic bacteria and aerobic mesophilic microorganisms were analyzed in milk. These same characteristics, except density and lactose, were also analyzed in cheeses. In addition, $\mathrm{pH}$, water activity, firmness, stickiness and color ( $\mathrm{L}^{*} \mathrm{a}^{*} \mathrm{~b}^{*}$, chroma and hue) were also analyzed in cheese. There was variation over the months in acidity, lactose and counts of thermotolerant coliform and lactic acid bacteria in milk. A higher acidity and lower lactose content as well as higher counts of thermotolerant coliform and lactic acid bacteria were observed in January, March, July, September and November. There were differences over the months for $\mathrm{pH}$, acidity, fat (dry weight), dry weight, firmness, stickiness, green color intensity $\left(-a^{*}\right)$, yellow color intensity $\left(b^{*}\right)$, chroma (C), water activity, and counts of thermotolerant coliforms and Staphylococcus spp. in cheeses. The results suggest that the moisture, dry matter and fat (dry weight) of cheeses are susceptible to relative air humidity and that the variations in these parameters can influence their firmness, adhesiveness, water activity and color. In milk and cheeses, the higher counts of
\end{abstract}


thermotolerant coliforms and Staphylococcus spp. were observed in January and November, when there is a higher air temperature and relative humidity.

Key Words: color; microbiology; physicochemical; seasonality; texture 


\section{INTRODUÇÃO}

Leite cru corresponde ao produto da ordenha completa, ininterrupta e higiênica de vacas sadias corretamente manejadas e não submetido a tratamento térmico, o qual utilizado como matéria-prima para a produção de inúmeros tipos de queijos, como o queijo Minas artesanal produzido na região do Serro, em Minas Gerais.

A produção do queijo Minas artesanal do Serro, geralmente em contexto da agropecuária familiar, é importante tanto pela geração de renda e ocupação, quanto por sua conotação sociocultural (Brant et al., 2007). Por estas razões, é considerado patrimônio imaterial e possuí certificado de indicação geográfica.

Em sua fabricação, ao leite cru recém-ordenhado, em temperatura pósejeção, são adicionados o coagulante enzimático e cultura lática natural não padronizada, denominada por pingo (Arcuri, 2013; Machado et al., 2004). De forma geral, no primeiro dia de fabricação se realiza a coagulação do leite cru, a adição do pingo, o corte da massa, a enformagem em formas com capacidade para um quilo, a dessoragem, a prensagem manual e o início da salga por adição de sal grosso na superfície. No segundo dia é realizada a viragem dos queijos nas formas, continua-se a salga e se coleta o pingo. No terceiro dia os queijos são desenformados, sua superfície é ralada, lixada, lavada para a remoção de imperfeições e se inicia a maturação por três dias, em sala própria e em condições ambientes. Posteriormente, os queijos são encaminhados à cooperativa, onde se realiza o controle de qualidade e onde são lavados, secos por 24 horas em câmara fria a $7^{\circ} \mathrm{C}$, embalados a vácuo, maturados por cinco dias em câmara fria a $7^{\circ} \mathrm{C}$ e expedidos.
Como este queijo é fabricado com leite cru não padronizado, seus aspectos químicos, microbiológicos e sensoriais podem ser influenciados por variações nas características da matéria prima (Maximiliano et al., 2009). Por esta razão, havendo possibilidade de variações sazonais em parâmetros de qualidade do leite cru, conforme descrito por Fagan et al. (2008), pressupõe-se que as características do queijo estejam a elas sujeitas. Sobre isto, Malacarne et al. (2005) descreveram que a sazonalidade de constituintes do leite, resultado da interação de fatores fisiológicos, climáticos e nutricionais, ao longo do ano, têm significante repercussão sobre a qualidade dos queijos. Além disto, estas variações afetam o rendimento de processos e a intensidade das transformações desejáveis durante a maturação. Há de se considerar os efeitos das diferentes épocas sobre a sua microbiota, no que diz respeito às contagens de bactérias de interesse tecnológico, patogênicas e deteriorantes (Maximiliano et al., 2011).

Conforme Yasmin et al. (2012) a sazonalidade na composição química e na microbiota do leite cru podem promover variações nas características sensoriais e nutricionais dos queijos, impactar sua aceitação de mercado e a credibilidade da cadeia produtiva em construir e manter um padrão de qualidade. Com a liberação para a comercialização do queijo Minas artesanal em território nacional, a falta de padrão sensorial, físico-químico e microbiológico seria ainda mais impactante.

Considerando-se o exposto esta pesquisa foi conduzida com o objetivo de se avaliar características do leite cru e do queijo Minas artesanal do Serro, Minas Gerais, produzidos em diferentes meses. 


\section{MATERIAL E MÉTODOS}

Do total de 32 propriedades do município do Serro, Minas Gerais, cadastradas no Instituto Mineiro de Agropecuária, em 2013, cinco foram aleatoriamente selecionadas para a coleta de leite cru e de queijos maturados por três dias e em expedição para a Cooperativa dos Produtores Rurais do Serro (COOPERSERRO).

Os rebanhos das propriedades sorteadas eram formados por fêmeas mestiças (Gir x Holandês), multíparas e em diferentes estádios de lactação. As coletas foram realizadas em janeiro, março, maio, julho, setembro e novembro, em 2013. As estimativas meteorológicas da região do Serro, neste período, são apresentadas na Tabela 1. Conforme controle da cooperativa a produção neste ano foi de, em média, 300 toneladas de queijo por mês, a qual principalmente escoada para o CEASA/MG e para outros pontos de venda da região.

\begin{tabular}{|c|c|c|c|c|c|c|}
\hline \multirow[b]{2}{*}{ Parâmetro } & \multicolumn{6}{|c|}{ Mês } \\
\hline & Janeiro & Março & Maio & Julho & Setembro & Novembro \\
\hline Estação & Verão & Outono & Outono & Inverno & Invemo & Primavera \\
\hline Precip mm 1 & 264,2 & 160,6 & 38,1 & 16,3 & 40,2 & 220,6 \\
\hline Temp min ${ }^{\circ} \mathrm{C}^{2}$ & 17,7 & 16,6 & 11,8 & 10,2 & 14,8 & 17,1 \\
\hline Temp máx ${ }^{\circ} \mathrm{C}^{3}$ & 28,5 & 27,5 & 24,7 & 22,4 & 24,3 & 26,2 \\
\hline UR\% min ${ }^{4}$ & 80,5 & 72,3 & 64,2 & 58,4 & 52,3 & 78,1 \\
\hline UR\% máx ${ }^{4}$ & 95,1 & 90,2 & 84,4 & 85,2 & 84,3 & 90,2 \\
\hline
\end{tabular}

Em cada um dos seis meses estudados foram coletadas, em cada propriedade, cinco amostras de $500 \mathrm{~mL}$ do leite cru recém-ordenhado e cinco queijos, sendo, ao todo, analisadas 150 amostras de leite cru e 150 amostras de queijo. O leite cru foi coletado imediatamente após a ordenha dos animais, a partir de volumes homogeneizados (amostra composta do rebanho) e imediatamente resfriado a $4^{\circ} \mathrm{C}$. Cada amostra de queijo correspondeu a uma peça inteira, com

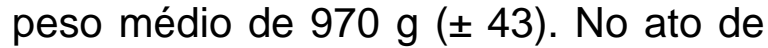
sua coleta, nas propriedades, os queijos foram embalados em sacos de polietileno, resfriados a $4^{\circ} \mathrm{C}$ e assim mantidos até o início das análises.

No leite cru foram determinadas, em triplicata, a acidez titulável, em graus Dornic $\left({ }^{\circ} \mathrm{D}\right)$, densidade corrigida para $15^{\circ} \mathrm{C}$, gordura pelo método de Gerber, umidade por gravimetria, massa seca total, proteína por semimicro Kjeldahl, lactose pelo método de Fehling e resíduo mineral fixo (Instituto Adolfo Lutz, 2008).

Os queijos foram assepticamente quarteados, em quatro porções, sendo primeiramente realizadas determinações de cor e obtidas alíquotas para o ensaio de textura. Posteriormente, foram triturados, sendo coletas alíquotas, em triplicadas, para as análises físicoquímicas e microbiológicas. Nos queijos foram determinados $\mathrm{o} \mathrm{pH}$, a acidez titulável (g.100g $\square 1$ de ácido lático), teor de gordura corrigida para massa seca pelo método de Gerber, umidade, massa seca total, proteína por semimicro Kjeldahl e resíduo mineral fixo (Instituto Adolfo Lutz, 2008). A atividade de água foi mensurada com higrômetro Aqualab (Decagon Devices Inc. USA).

A luminosidade $\left(L^{*}\right)$, intensidade de vermelho-verde $\left(a^{*}\right)$ e intensidade de amarelo-azul $\left(b^{*}\right)$ dos queijos foram determinadas com colorímetro Chroma Meter CR-400 (Konica Minolta, Japão), empregando-se o iluminante D 65 . Os valores foram expressos no sistema CIELAB. Calculou-se o matiz $\left(H^{\circ}=\right.$ $\left.\arctan b^{*} / a^{*}\right)$ e croma $\left[C=\left(a^{*} 2+b^{*} 2\right)\right.$ $1 / 2]$, conforme descrito em Konica Minolta Sensing (2007). As mensurações de luminosidade e de cor foram realizadas no centro geométrico dos queijos, em triplicata.

A firmeza (g) e a adesividade (g.s-1) dos queijos foram mensuradas com texturômetro TA.XT2 plus ${ }^{\circledR}$ Stable 
Características do leite cru e do queijo minas...

Micro Systems acoplado com a sonda de fio metálico. Amostras, coletadas na região central dos queijos, foram preparadas em formato cilíndrico com $20 \mathrm{~mm}$ de diâmetro e $20 \mathrm{~mm}$ de altura. Os dados de firmeza (picos positivos máximos) e adesividade (áreas negativas do gráfico) foram obtidos empregando-se o programa Exponent Lite versão 5.1 (Stable Micro Systems). O equipamento foi calibrado com peso padrão de $5 \mathrm{~kg}$, com velocidade de descida e de corte do dispositivo de 200 $\mathrm{mm}$ minuto-1, velocidade de pré-teste, teste e de pós-teste de $2 \mathrm{~mm} \mathrm{~s}-1$ e distância de penetração de $15 \mathrm{~mm}$.

No leite cru e nos queijos foram quantificados coliformes totais, coliformes termotolerantes, Staphylococcus spp., Staphylococcus coagulase positiva, bactérias láticas e micro-organismos aeróbios mesófilos, conforme Silva et al. (2010).

O experimento foi conduzido em delineamento inteiramente casualizado, em arranjo fatorial com seis tratamentos (meses do ano), cinco propriedades e cinco repetições. Os dados foram submetidos à análise de variância e ao teste de Tukey, em probabilidade de $5 \%$, utilizando-se o programa Statistical Analysis System (SAS, 2002).

\section{RESULTADOS E DISCUSSÃO}

Não houve interação $(P>0,05)$ entre os parâmetros avaliados e propriedades nas quais foram coletadas as amostras, ao longo dos meses pesquisados. As características do leite cru e do queijo Minas artesanal do Serro, Minas Gerais, produzidos em diferentes meses, são apresentadas nas Tabelas 2 e 3.
Tabela 2 - Características físico-químicas e microbiológicas do leite cru produzido no Serro, Minas Gerais, em diferentes meses.

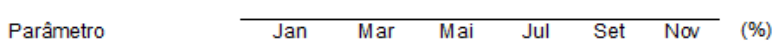

\begin{tabular}{llllllll}
\hline Acidez ${ }^{\circ} \mathrm{D}$ & $19,10 \mathrm{a}$ & $18,5 \mathrm{a}$ & $15,4 \mathrm{~b}$ & $18,4 \mathrm{~b}$ & $18,5 \mathrm{a}$ & 18,7 a & 1,5
\end{tabular}
$\begin{array}{llllllll}\text { Densidade g. } \mathrm{mL}^{-1} & 1,032 & 1,029 & 1,030 & 1,030 & 1,029 & 1,031 & 1,01\end{array}$ $\begin{array}{llllllll}\text { Gordura g. } 100 \mathrm{~g}^{-1} & 3,78 & 4,10 & 3,70 & 3,71 & 3,90 & 3,82 & 5,61\end{array}$ $\begin{array}{llllllll}\text { Umidade g.100g-1 } \quad 87,64 & 86,82 & 87,14 & 87,25 & 87,52 & 87,74 & 1,43\end{array}$ $\begin{array}{llllllll}\text { MST }^{1} \text { g.100g-1 } & 11,56 & 13,18 & 12,86 & 12,75 & 12,48 & 12,26 & 6,33\end{array}$ $\begin{array}{llllllll}\text { Proteína g. } 100 \mathrm{~g}^{-1} & 3,35 & 3,61 & 3,25 & 3,57 & 3,67 & 3,45 & 2,36\end{array}$ $\begin{array}{llllllll}\text { Lactose g. } 100 \mathrm{~g}^{-1} & 4,14 \mathrm{~b} & 4,0 \mathrm{~b} & 4,67 \mathrm{a} & 3,79 \mathrm{~b} & 3,74 \mathrm{~b} & 3,65 \mathrm{~b} & 1,86\end{array}$ $\begin{array}{llllllll}\text { RMF }^{2} \text { g. } 100 \mathrm{~g}^{-1} & 0,74 & 0,76 & 0,71 & 0,78 & 0,73 & 0,77 & 2,74\end{array}$

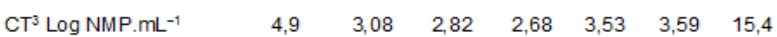

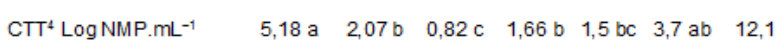
$\begin{array}{llllllll}\mathrm{Sph}^{5} \text { Log UFC. } \mathrm{mL}^{-1} & 5,87 & 5,20 & 4,47 & 4,37 & 5,30 & 4,78 & 14,6\end{array}$

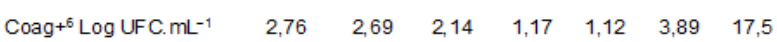
$\begin{array}{lllllllll}\text { BL }^{7} \log \text { UFC. mL } & -1 & 7,22 \mathrm{a} & 4,75 \text { b } & 5,15 \text { b } & 4,58 \text { b } & 5,0 \text { b } & 6,15 \text { b } & 21,1\end{array}$

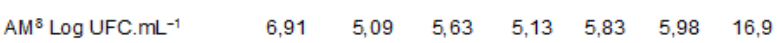

1Massa seca total. ${ }^{2}$ Resíduo mineral fixo. ${ }^{3}$ Coliformes totais. ${ }^{4}$ Coliformes termotolerantes. ${ }^{5}$ Staphylococcus spp. ${ }^{6}$ Staphylococcus coagulase positiva. 'Bactérias láticas. ${ }^{\circ}$ Aeróbios mesófilos.

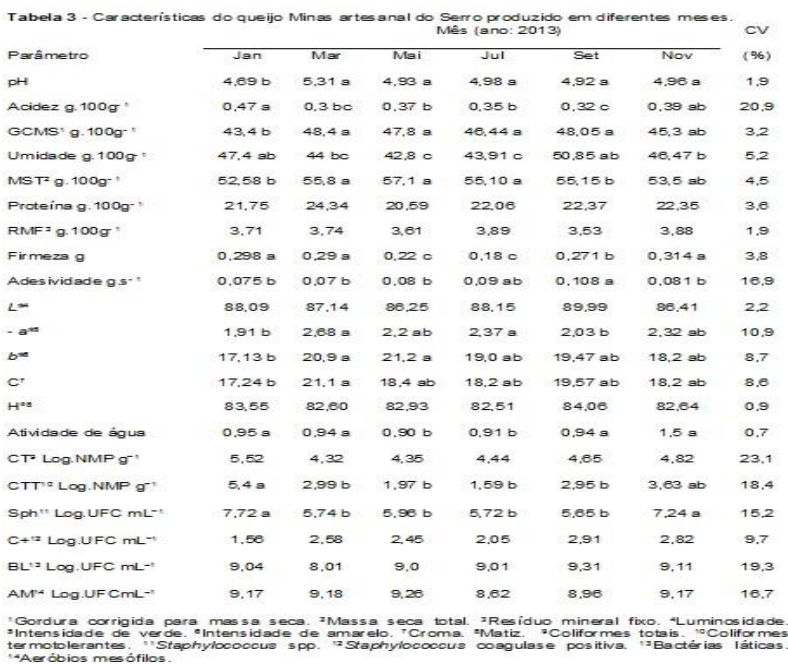

No leite cru a densidade, teor de gordura, umidade, massa seca total, proteína, resíduo mineral fixo e contagens de coliformes totais, Staphylococcus spp., Staphylococcus coagulase positiva e de microorganismos aeróbios mesófilos foram semelhantes $(P>0,05)$ ao longo dos meses pesquisados. Os parâmetros físico-químicos atenderam aos critérios vigentes para o leite cru, os quais estabelecem densidade dentre 1,028 a 1,034 g.mL $\square 1$, mínimo de 3 g.100g $\square 1$ de gordura, mínimo de $2,9 \mathrm{~g} .100 \mathrm{~g} \square 1 \mathrm{de}$ 
proteína, máximo de máximo 88,5 g. $100 \mathrm{~g}^{-1}$ de umidade e o mínimo de 11,5 g.100 $\mathrm{g}^{-1}$ de massa seca (Brasil, 2011; Minas Gerais, 2002).

Nos queijos recém-fabricados não se observou diferença significativa $(P>0,05)$ nos teores de proteína, resíduo mineral fixo, contagens de coliformes totais, Staphylococcus coagulase positiva, bactérias láticas, microorganismos aeróbios mesófilos, luminosidade $\left(\mathrm{L}^{*}\right)$ e matiz $\left(\mathrm{H}^{\circ}\right)$ ao longo dos meses avaliados.

A acidez titulável, lactose, resíduo mineral fixo e contagens de coliformes termotolerantes e bactérias láticas no leite foram diferentes $(P<0,05)$ ao longo dos meses avaliados. Para os queijos recém-fabricados foram observadas diferenças $(\mathrm{P}<0,05)$ para $\mathrm{pH}$, acidez titulável, gordura corrigida para a massa seca, umidade, massa seca total, atividade de água e contagens de coliformes termotolerantes

Staphylococcus spp.

Menor acidez titulável do leite foi observada em maio, período que em que também apresentou maior teor de lactose. Não foi possível identificar, na rotina de produção o porquê deste mês apresentar esta peculiaridade. Entretanto, chama a atenção por ter apresentado, também, menor contagem de coliformes termotolerantes, os quais são capazes de fermentar a lactose e produzir ácido lático (Silva et al., 2012; Fagan et al., 2008).

Tão importante quanto observar esta especificidade em maio se faz avaliar 0 comportamento destes parâmetros nos demais meses, nos quais a contagem de coliformes termotolerantes foi maior, o que pode ter contribuído para a maior acidez e menor teor de lactose, principalmente em novembro e janeiro. Há de se mencionar que, com exceção de maio, nos demais meses o teor de lactose foi inferior ao limite mínimo de $\quad 4,3 \quad$ g.100g $\square 1$ estabelecido pela legislação (Minas Gerais, 2002).

Embora a acidez titulável do leite tenha sido superior ao limite máximo de $18^{\circ} \mathrm{D}$ (Brasil, 2011), ainda assim permaneceu dentro do intervalo de 15 a $20^{\circ} \mathrm{D}$ preconizado como normal pela legislação estadual que rege a produção de queijo Minas artesanal (Minas Gerais, 2002). Nesta legislação há maior tolerância para este parâmetro, pois o leite cru não é submetido a resfriamento após ordenha, sendo diretamente destinado ao processamento do queijo.

Conforme Fagan et al. (2008) a elevada acidez do leite cru pode ser consequência da contaminação e da atividade de micro-organismos fermentadores da lactose, as quais decorrem de falhas nos procedimentos operacionais de higiene durante a ordenha e no pré-beneficiamento do leite. Por esta razão, mesmo havendo tolerância da legislação estadual para a acidez do leite, há necessidade de se investir em procedimentos mais adequados para a sua produção.

Maior acidez titulável do queijo foi observada $(P<0,05)$ em janeiro e coincidiu com maior acidez do leite, com maiores contagens de coliformes termotolerantes e de bactérias láticas no leite e com maiores contagens de coliformes termotolerantes no queijo. Em janeiro também foi constatado $(\mathrm{P}<0,05)$ menor $\mathrm{pH}$, o qual ocasionado pela maior concentração de ácido lático e, consequentemente, maior concentração de prótons hidrogênio $(\mathrm{H}+)$ liberados no processo de acidificação do leite.

Ambos os parâmetros são relevantes aos queijos, pois influenciam na atividade das proteases e lipases, enzimas que agem durante a maturação, e no desenvolvimento de micro-organismos presentes no produto. Os valores de $\mathrm{pH}$ observados nesta pesquisa (de 4,69 a 5,31) são 
semelhantes aqueles relatados no queijo do Serro por Machado et al. (2004), que observaram uma média 4,98 , e inferiores aos observados no queijo Canastra por Silva et al. (2011) que obtiveram uma média de 5,14 na época chuvosa e de 5,36 na época seca.

A acidez do queijo foi 0 parâmetro físico-químico com maior coeficiente de variação o que, segundo Lavasani et al. (2011) e Silva et al. (2011), decorre de variações na quantidade de bactérias fermentadoras da lactose, presentes no leite cru, assim como de variações no processo de fabricação, principalmente nas etapas de prensagem e de salga. Além disto, há influência de variações na contagem de bactérias láticas no pingo, tendo em vista se tratar de um inoculo natural composto por bactérias nativas e não padronizado.

A variação nos teores de lactose do leite, ao longo dos meses, foi diferente do comportamento relatado por Gonzalez et al. (2004) e Martins et al. (2006), os quais observaram menores quantidades deste dissacarídeo em maio. Gonzáles et al. (2004) relacionaram o menor teor de lactose com a maior incidência de mastite, em cuja ocorrência pode haver migração intramamária da lactose do leite para o sangue, além da lesão tecidual do epitélio mamário e a redução de sua capacidade de biossíntese deste glicídio.

Noro et al. (2006) observaram maior teor de lactose em agosto $(4,6$ g.100g-1) e menor teor em março $(4,46$ g.100g-1) e justificaram esta variação em função da melhor qualidade dos alimentos fornecidos aos animais durante $o$ inverno e por sua menor qualidade durante o verão, assim como o estresse térmico em épocas mais quentes. Estes autores também observaram que o teor de lactose reduziu significativamente com o avanço da lactação e com o aumento da idade ao parto. Entretanto, como as amostras coletadas nesta pesquisa foram compostas e os rebanhos das propriedades rurais do Serro são heterogêneos, com relação a estes critérios, não sendo possível direcionar a discussão neste sentido. Sugere-se, portanto, pesquisas para avaliar a heterogeneidade de rebanhos na pecuária familiar e sua influência nas sobre características da matéria-prima.

Além dos aspectos sanitários e produtivos dos rebanhos, anteriormente abordados, observou-se, nesta pesquisa, coincidência entre menor teor de lactose no leite, maior acidez e maior contagem de fermentadores. Sugere-se, portanto, pesquisas para avaliar efeitos da densidade populacional de fermentadores nos quantitativos deste glicídio no leite cru.

Chen et al. (2014) relatou variações significativas no teor de gordura do leite, em diferentes épocas, as quais justificadas por diferenças na qualidade do pasto e dos alimentos fornecidos aos animais. Nesta pesquisa, no entanto, tais variações não foram observadas, o que permite presumir que mesmo havendo diferenças na composição dos alimentos e no manejo, ao longo dos meses, não foram elas suficientes para promover variações no quantitativo de lipídeos. Com relação a isto, Martins et al. (2006) e Gonzáles et al. (2004) também não verificaram efeito significativo de meses e épocas do ano no teor de gordura do leite cru produzido na bacia leiteira de Pelotas, Rio Grande do Sul.

Nos queijos, ao contrário do leite, foram observadas variações $(P<0,05)$ no teor de gordura corrigida para a massa seca, sendo menor naqueles produzidos em janeiro. Havendo semelhança, portanto, no teor de gordura da matéria-prima presume-se que tais variações sejam devidas aos métodos de produção dos queijos. 
A gordura corrigida para a massa seca e massa seca total dos queijos foram maiores $(P<0,05)$ nos meses que apresentaram menor umidade relativa do ar (março, maio, julho e setembro). Nestes períodos foi também observado $(\mathrm{P}<0,05)$ um menor teor de umidade dos queijos. Entretanto, mesmo havendo variações, os queijos mantiveram-se conformes as exigências legais de no máximo $54 \mathrm{~g} .100 \mathrm{~g} \square 1$ de umidade e de no mínimo de 46 g.100g $\square 1$ de massa seca total (Minas Gerais, 2002).

Devido ao fato deste produto ser resultado de processo manual, é compreensível a dificuldade de se padronizar algumas etapas como a prensagem $e$ a salga e, consequentemente, a intensidade da sinérese (Silva et al., 2011). Por tais razões, os queijos podem apresentar teores de umidade e de massa seca variáveis, 0 que influencia as transformações durante a maturação, assim como a sua cor, luminosidade, matiz, croma, atividade de água e desenvolvimento microbiano.

Considerando-se que os queijos são maturados por três dias na propriedade, em local fechado designado por quarto de queijo, sem embalagem e em condições ambientes, há possibilidade de maior perda de umidade por evaporação em meses com menor umidade relativa do ar, o que promove a concentração de sólidos totais, como a gordura. Semelhante a isto, Machado et al. (2004) mencionaram que, além da técnica de fabricação empregada, a umidade relativa e a temperatura ambiente do local de maturação são fatores que interferem nas características dos queijos artesanais. Como há interesse na produção de queijos com características mais uniformes ao longo do ano, há de se avaliar alternativas para se reduzir os efeitos locais do quarto de queijo sobre a maturação e características do produto.
No decorrer da condução desta pesquisa os produtores, em comunicação informal, relataram maior preferência do consumidor por queijos produzidos na época das secas, os quais são descritos como sendo mais macios e untuosos. Conforme observado, os queijos desta época apresentaram $(P<0,05)$ maior teor de gordura corrigida para matéria seca, menor firmeza e maior adesividade. Informalmente o queijo das águas foi descrito como sendo mais seco e quebradiço.

Conforme Valle et al. (2004) a firmeza e a adesividade são influenciadas pelo teor de gordura da matriz, sendo que quanto maior o teor de gordura, menor a firmeza e maior a adesividade dos queijos.

As variações nos teores de gordura corrigida para a massa seca (GCMS) e umidade, provavelmente decorrentes das condições ambientes da câmara de maturação, influenciaram na classificação dos queijos (Brasil, 1996). Os queijos produzidos em janeiro foram classificados como sendo semigordos (GCMS de 24 a 44,9 g.100g-1) e, nos demais meses, foram classificados como queijos gordos (GCMS de 45 a 59,9 g.100g-1). Os queijos produzidos em janeiro, setembro e novembro foram considerados de alta umidade (umidade de 46 a 54,9 g.100g-1) e em março, maio e julho como de média umidade (umidade de 36 a 45,9 g.100g-1).

Com relação a parâmetros de cor de queijos houve variação $(P<0,05)$ na intensidade de verde $\left(-a^{*}\right)$, na intensidade de amarelo $\left(b^{*}\right)$ e no croma ao longo dos meses avaliados.

Carotenoides são importantes pigmentos cromogênicos do leite e dos queijos e seu teor depende da quantidade presente na dieta dos animais (Perry, 2004). Por sua natureza lipossolúvel estes constituintes se distribuem nos glóbulos de gordura e, 
por esta razão, quanto maior a quantidade de glóbulos maior tende a ser a sua participação na formação da cor da matriz alimentar. Este contexto contribui para que fosse compreendida, então, a maior $(\mathrm{P}<0,05)$ intensidade de amarelo $\left(b^{*}\right)$ nos meses de em que também foi observado maior teor de gordura corrigida para matéria seca dos queijos. Nestes meses (março, maio, julho e setembro) os queijos apresentaram menor umidade $e$, consequentemente, maior teor de sólidos. Este fato pode ter contribuído, também, para a concentração de pigmentos que conferiram maior intensidade de verde $\left(-a^{*}\right)$, dentre os quais Wold et al. (2005) mencionam os resíduos naturais de porfirinas e clorofilas. Maior croma, ou seja, maior vivacidade de cores, aconteceu nos meses de maior teor de massa seca, sendo proporcionado pela maior intensidade nos teores de verde e de amarelo.

Mesmo havendo diferenças nas intensidades de verde e de amarelo estas não foram suficientes para promover variações significativas no matiz $\left(\mathrm{H}^{\circ}\right)$, ou seja, os queijos mantiveram uma cor semelhante, em seu centro geométrico e, provavelmente, o sistema sensorial humano não seria sensível a estas variações. Pela proximidade do ângulo do matiz $\left(\mathrm{H}^{\circ}\right)$ a $90^{\circ}$ considera-se que a cor predominante dos queijos é a amarela (Konica Minolta Sensing, 2007).

A luminosidade corresponde ao efeito ótico proporcionado pela reflexão da luz que incide sobre a amostra e o componente da matriz alimentar mais envolvido neste processo é a água. Quanto maior o teor de umidade, maior a luminosidade. Embora tenha havido diferença no teor de umidade dos queijos, ao longo dos meses, estas variações não foram influenciaram a luminosidade do produto.
A atividade de água dos queijos apresentou valores distintos $(P<0,05)$ durante os meses avaliados, sendo menor valor observado nos queijos produzidos em maio e julho, os quais apresentam menor umidade e maior teor de massa seca. Conforme Henao et al. (2009) este parâmetro pode ser entendido como a medida da água disponível em um alimento, ou seja, não vinculada a componentes, sendo assim passível de se reagir quimicamente e permitir o desenvolvimento microbiano. No leite cru as contagens de coliformes termotolerantes e de bactérias láticas foram maiores $(P<0,05)$ em novembro e janeiro, meses com as maiores temperaturas, precipitação e umidade relativa do ar. Nestes mesmos meses foram observadas $(P<0,05)$ maiores contagens de coliformes termotolerantes e Staphylococcus spp. nos queijos. Além das condições meteorológicas deste período, mais propicias à multiplicação bacteriana, os queijos apresentaram maior atividade de água, o que pode ter favorecido 0 desenvolvimento destes microorganismos.

Os efeitos de diferentes condições climáticas sobre a microbiota do leite cru já foram abordadas na literatura (Maximiliano et al., 2011). Em verões chuvosos, como ocorre tipicamente na região do Serro, há maior solubilização de matéria orgânica o que, somado às temperaturas mais elevadas, favorece a proliferação de micro-organismos no ambiente, principalmente no solo (Fraga et al., 2012; Rodrigues et al., 2011). Há, portanto, maior dificuldade para 0 produtor em se praticar, corretamente, os procedimentos de higiene antes, durante e após a ordenha, e riscos de maior quantidade de fontes de contaminação. Em meses com menores índices pluviométricos e com menor temperatura, ao contrário, a proliferação microbiana ambiental tende a ser 
menor, repercutindo em menor contaminação cruzada. Tais efeitos são pertinentes para se compreender as variações nas contagens de coliformes termotolerantes e bactérias láticas no leite e também nas contagens de coliformes termotolerantes

Staphylococcus spp. nos queijos.

A presença de coliformes termotolerantes, além do ônus econômico e nutricional, pela degradação da lactose, pode interferir negativamente na segurança dos queijos, tendo em vista que muitas espécies deste grupo já foram associadas à ocorrência de doenças, como Escherichia coli, Campyblobacter jejuni e Salmonella spp. (Hill et al., 2012; Tebaldi et al., 2008). Somado a isto, a proliferação destes fermentadores pode ocasionar o acúmulo de dióxido de carbono e a formação de olhaduras gasosas, as quais entendidas como sendo defeito em queijos.

A legislação vigente não institui requisitos para as contagens de coliformes totais e termotolerantes no leite cru (Brasil, 2011; Minas Gerais, 2002). Para o queijo artesanal, no entanto, estabelece-se o máximo para coliformes totais de 4 Log NMP.g-1 e para coliformes termotolerantes de 3,69 Log NMP.g-1 (Minas Gerais, 2002). Ao se confrontar estes critérios com os dados desta pesquisa observou-se que, em todos os meses avaliados, as contagens de coliformes totais foram superiores ao limite estabelecido pela legislação. As contagens médias de coliformes termotolerantes excederam o limite máximo em janeiro $(5,4$ Log NMP.g-1) e em novembro estiveram próximas ao limite superior (3,43 Log NMP.g-1).

As contagens de coliformes totais e termotolerantes desta pesquisa foram semelhantes aquelas relatadas, em queijo Minas artesanal, por Resende et al. (2011), as quais de 4,45 Log NMP.g-1 e 3,65 Log NMP.g-1, respectivamente. Estes autores sugeriram que as elevadas contagens deveram-se às condições sanitárias dos rebanhos, à qualidade do leite, às diferenças nos métodos de fabricação, transporte, comercialização e estocagem. Conforme Brant et al. (2007) estes micro-organismos geralmente são contaminantes ambientais e contagens elevadas indicam deficiências na implementação das boas práticas agropecuárias para produção do leite cru e das boas práticas de fabricação dos queijos.

A contagem máxima permitida para Staphylococcus coagulase positiva em queijos artesanais mineiros é de 3 Log UFC.g-1 (Minas Gerais, 2002). Nesta pesquisa observou-se contagem média, de todos os meses, de 2,4 Log UFC.g-1, a qual inferior ao máximo permitido pela legislação. Conforme Sant'ana e Azeredo (2005) estes microorganismos produzem enterotoxinas termoestáveis e em contagens superiores a 5 Log UFC.g $\square 1$ há risco de que haja toxina em quantidade suficiente para desencadear intoxicação alimentar. Conforme Silva et al. (2010) e Arcuri et al. (2006) as fontes de introdução mais comuns destes microorganismos são os portadores humanos assintomáticos, as superfícies contaminadas, o úbere de animais e a utilização de leite proveniente de fêmeas com mastite.

As contagens de Staphylococcus coagulase positiva, observadas nesta pesquisa, foram inferiores àquelas relatadas no queijo artesanal do Serro (5,4 UFC.g $\square 1$ ) por Brant et al. (2007). A maioria (cerca de 80\%) das colônias coagulase positiva apresentou morfologia atípica (ausência de halo em ágar Baird Parker).

As contagens de microorganismos aeróbios mesófilos, tanto no leite, quanto nos queijos, não foram influenciadas $(p>0,05)$ pelos meses. $O$ limite máximo para a contagem destes 
micro-organismos no leite cru é de 5 Log UFC.mL $\square 1$ (Minas Gerais, 2002) e de 4 Log UFC.mL $\square 1$ (Brasil, 2011). As médias observadas nesta pesquisa foram superiores aos limites estabelecidos pela legislação e isto provavelmente se deve à implementação inadequada das boas práticas (Fagan et al., 2008).

As contagens de bactérias láticas no leite foram distintas $(P<0,05)$ nos meses avaliados, sendo maiores em janeiro. Ao contrário dos demais grupos estudados, estas bactérias são indispensáveis para a fabricação de queijos artesanais devido à acidificação que proporcionam e por contribuir com a formação de características sensoriais desejáveis aos queijos, durante a sua maturação (Perry, 2004).

As contagens de coliformes totais e termotolerantes, Staphylococcus spp., Staphylococcus coagulase positiva e, principalmente, de bactérias láticas e de micro-organismos aeróbios mesófilos foram maiores nos queijos do que no leite cru, o que pode ter sido ocasionado pela proliferação da microbiota inicial e, também, por contaminação cruzada durante o processamento do queijo.

Intervenções tecnológicas nos processos poderiam amenizar variações sazonais nos teores de umidade e de gordura corrigida para a massa seca e, portanto, na firmeza e adesividade dos queijos, parâmetros que influenciam na sua aceitação. Deve-se manter e planejar mais investimentos em boas práticas agropecuárias e de fabricação para se assegurar a melhor qualidade microbiológica do leite e dos queijos.

\section{CONCLUSÃO}

O leite cru e os queijos produzidos nos meses de janeiro e novembro, com maior índice pluviométrico, temperatura e umidade relativa do ar apresentaram maiores contagens de coliformes termotolerantes, bactérias láticas e Staphylococcus spp. O leite produzido em maio apresentou menor acidez e maior teor de lactose. Nos demais meses a acidez titulável foi elevada e coincidiu com menor teor de lactose e com maiores contagens de coliformes termotolerantes e bactérias láticas. Nos queijos produzidos nos meses de maio e julho, em que tipicamente há menor umidade relativa do ar, foram observados maior teor de massa seca, menor teor de umidade e maior teor de gordura corrigida para a matéria seca, o que resultou em menor atividade de água, menor firmeza, maior adesividade, maior intensidade de verde, maior intensidade de amarelo e maior croma. As variações na gordura corrigida para a massa seca e na umidade repercutiram-na classificação dos queijos. Aqueles produzidos em janeiro foram classificados como semigordos e nos demais meses como gordos. Os queijos produzidos em janeiro, setembro e novembro foram classificados como de alta umidade e em março, maio e julho como de média umidade.

\section{REFERÊNCIAS}

ARCURI, E.F.; BRITO, M.V.A.P; BRITO, J.F.R. et al. [2006]. Qualidade microbiológica do leite refrigerado nas fazendas. Arquivo Brasileiro de Medicina Veterinária e Zootecnia, v.58, n.3, p.440-446, 2006. Disponível em: $<$ http://www.scielo.br/pdf/abmvz/v58n3/3 1041.pdf>. Acesso em: 02/03/2014.

ARCURI, E.F.; SHEIKHA, A.F.E.; RYCHLIK, T. et al. [2013]. Determination of cheese origin by using 16S rDNA fingerprinting of bacteria communities by PCR-DGGE: Preliminary application to traditional Minas cheese. Food Control, v.30, n.1, p.1-6, 2013. Disponível em: <http://www.sciencedirect.com/science/a 
rticle/pii/S0956713512003982>. Acesso em: 14/02/2014.

BRANT, L.M.F.; FONSECA, L.M.; SILVA, M.C.C. [2007]. Avaliação da qualidade microbiológica do queijo-deminas artesanal do Serro-MG. Arquivo Brasileiro de Medicina Veterinária e Zootecnia, v.59, n.6, p.1570-1574, 2007. Disponível em:

$<$
http://www.scielo.br/pdf/abmvz/v59n6/33 .pdf>. Acesso em: 25/03/2014.

BRASIL. Ministério da Agricultura, Pecuária e Abastecimento. Instrução Normativa $\mathrm{N}^{\circ} 30$ de 07 de agosto de 1996. Disponível em: $<$ http://agricultura.gov.br>. Acesso em: 12/02/2014.

BRASIL. Ministério da Agricultura, Pecuária e Abastecimento. Instrução Normativa $\mathrm{N}^{\circ} 62$ de 29 de dezembro de 2011. Disponível em: <http://agricultura.gov.br>. Acesso em: 11/11/2013.

BRASIL. Ministério da Agricultura, Pecuária e Abastecimento. Instrução Normativa $\mathrm{N}^{\circ} 30$ de 07 de agosto de 2013. Disponível em: $<$ http://agricultura.gov.br>. Acesso em: 21/01/2014.

CEMIG. Companhia Energética do Estado de Minas Gerais. Meteorologia: previsão do tempo em regiões de Minas Gerais. Disponível em: <http://www.cemig.com.br/ptbr/Meteorologia/Paginas/default.aspx>. Acesso de 01/01/2013 a 20/12/2013.

CHEN, B.; LEWIS, M.J.; GRANDISON, A.S. [2014]. Effect of seasonal variation on the composition and properties of raw milk destined for processing in the UK. Food Chemistry, v.158, n.1, p.216-223, $2014 . \quad$ Disponível em: <http://www.sciencedirect.com/science/a rticle/pii/S0308814614003033>. Acesso em: 15/05/2014.

FAGAN, E. P. et al. [2008]. Avaliação de padrões físico-químicos microbiológicos do leite em diferentes fases de lactação nas estações do ano em granjas leiteiras no Estado do Paraná - Brasil. Semina Ciências Agrárias, v. 29, n. 3, p. 651-660, 2008.

FRAGA, M.E.; BRAZ, D.M.; ROCHA, J.F. et al. [2012] Interação microrganismo, solo e flora como condutores da diversidade na Mata Atlântica. Acta Botânica Brasilica, v.26, n.4, p.857-865, 2012. Disponível em: <http://www.scielo.br/pdf/abb/v26n4/15. pdf>. Acesso em: 15/02/2014.

GONZALEZ, H.L.; FISCHER, V.; RIBEIRO, M.E.R. et al. [2004]. Avaliação da qualidade do leite na bacia leiteira de Pelotas, RS: efeito dos meses do ano. Revista Brasileira de Zootecnia, v.33, n.6, p.1531-1543, 2004. Disponível em:

<http://www.scielo.br/pdf/rbz/v33n6/a20v 33n6.pdf>. Acesso em: 15/12/2013.

HENAO, J.D.; QUEIROZ, M.R.; HAJISA, N.M.A. [2009]. Umidade de equilíbrio de café cereja descascado baseadas em métodos estático e dinâmico. Revista Brasileira de Engenharia Agrícola e Ambiental, v.13, n.4, p.470-476, 2009. Disponível em: < http://www.scielo.br/pdf/rbeaa/v13n4/v13 n4a15.pdf>. Acesso em: 18/04/2014.

HILL, B.; SMYTHE, B.; LINDSAY, D. et al. [2012]. Microbiology of raw milk in New Zealand. International Journal of Food Microbiology, v.157, n.2, p.305308, 2012. Disponível em: <http://www.sciencedirect.com/science/a rticle/pii/S0168160512001717>. Acesso em: 04/03/2014.

INSTITUTO ADOLFO LUTZ. [2008]. Métodos físico-químicos para análise de alimentos. 4. ed. 1. ed. digital. São Paulo: Instituto Adolfo Lutz, 2008, 1020p. Disponível em: $<w w w . i a l . s p . g o v . b r>$. Acesso em: 01/01/2013.

KONICA MINOLTA SENSING. Precise color communication: color control from 
perception to instrumentation. Konica Minolta Sensing Incorporated, 2007.

LAVASANI, A.R.S.; EHSANI, M.R.; MIRDAMADI, S. et al. [2011]. Changes in physicochemical and organoleptic properties of traditional Iranian cheese Lighvan during ripening. International Journal of Dairy Technology, v.65, n.1, p.64-70, 2011. Disponível em: <http://onlinelibrary.wiley.com/doi/10.11 11/j.1471-0307.2011.00724.x/pdf>.

Acesso em: 16/03/2013.

MACHADO, E. C.; FERREIRA, C.L.L.F; FONSECA, L.M. et al. [2004]. Características físico-químicas e sensoriais do queijo Minas artesanal produzido na região do Serro, Minas Gerais. Ciência e Tecnologia de Alimentos, v.24, n.4, p.516-521, 2004. Disponível em: <http://www.scielo.br/pdf/cta/v24n4/a06v 24n4.pdf>. Acesso em: 03/02/2014.

MALACARNE, M. et al. Seasonal variations of herd milk quality in parmigiano-reggiano cheese manufacture: comparison between jersey and Italian friesian cattle breeds. Annali della Facolta di Medicina Veterina del Studi di Parma, v.25, p.145-166, 2005.

MARTINS, P.R.G.; SILVA, C.A.; FISCHER, V. et al. [2006] Produção e qualidade do leite na bacia leiteira de Pelotas-RS em diferentes meses do ano. Ciência Rural, v.36, n.1, p.209-214, 2006. Disponível em: <http://www.scielo.br/pdf/cr/v36n1/a32v3 6n1.pdf>. Acesso em: 22/01/2014.

MAXIMILIANO, S.P.; CARVALHO, A.F.; PIRES, A.C.S. et al. [2009]. Survival of Listeria innocua in Minas Traditional Serro cheese during pipening. Food Control, v.20, n.12, p.1167-1170, 2009. Disponível em: <http://www.sciencedirect.com/science/a rticle/pii/S0956713509000553>. Acesso em: 17/02/2014.
MAXIMILIANO, S.P.; CARVALHO, A.F.; PIRES, A.C.S. et al. [2011]. The effects of nisin on Staphylococcus aureus count and the physicochemical properties of Traditional Minas Serro cheese. International Dairy Journal, v.21, n.2, p.90-96, 2011. Disponível em: <http://www.sciencedirect.com/science/a rticle/pii/S0958694610001986>. Acesso em 15/03/2014.

MINAS GERAIS. Lei N ${ }^{\circ} 14185$ de 31 de janeiro de 2002. Processo de Produção do Queijo Minas Artesanal. <http://www.almg.gov.br/consulte/legisla cao/completa/completa.html?ano=2002 \&num $=14185 \&$ tipo $=$ LEl $>$. Acesso em: 11 nov. 2013.

NORO, G.; GONZÁLES, F.H.D.; CAMPOS, R. et al. [2006]. Fatores ambientais que afetam a produção e a composição do leite em rebanhos assistidos por cooperativas no Rio Grande do Sul. Revista Brasileira de Zootecnia, v.35, n.3, p.1129-1135, 2006. Disponível em:

http://www.scielo.br/pdf/rbz/v35n3s0/307 27.pdf >. Acesso em: 05/02/2014.

PERRY, K.S.P. [2004]. Queijos: aspectos químicos, bioquímicos e microbiológicos. Química Nova, v.27, n.2, p.293-300, 2004. Disponível em: <http://www.scielo.br/pdf/qn/v27n2/1927 6.pdf>. Acesso em: 18/02/2014.

RESENDE, M.F.S.; COSTA, H.H.S.; ANDRADE, E.H.P. et al. [2011]. Queijo de minas artesanal da Serra da Canastra: influência da altitude das queijarias nas populações de bactérias acidolácticas. Arquivo Brasileiro de Medicina Veterinária e Zootecnia, v.63, n.6, p.1567-1573, 2011. Disponível em: $<$ http://www.scielo.br/pdf/abmvz/v63n6/3 9.pdf>. Acesso em: 15/12/2013.

RODRIGUES, H.J.B.; SÁ, L.D.A.; RUIVO, M.L.P. B. et al. [2011]. Variabilidade quantitativa de população microbiana associada às condições microclimáticas observadas em solos de 
floresta tropical úmida. Revista Brasileira de Meteorologia, v. 26, n. 4, p. 629-638, 2011. Disponível em: <http://www.scielo.br/pdf/rbmet/v26n4/a 12v26n4.pdf>. Acesso em: 11/02/2014.

SANT'ANA, A.S.; AZEREDO, D.R.P. [2005]. Comparação entre o sistema Petrifilm RSA $\AA$ e a metodologia convencional para a enumeração de estafilococos coagulase positiva em alimentos. Ciência e Tecnologia de Alimentos, v.25, n.3, p.531-535, 2005. Disponível em: < http://www.scielo.br/pdf/cta/v25n3/27023 .pdf>. Acesso em: 05/03/2014.

SAS. STATISTICAL ANALYSIS SYSTEMS. User's guide: Version 9.1. Cary: 2002, v.2, 1052p.

SILVA, N.; JUNQUEIRA, V.C.A.; SILVEIRA, N.F.A. et al. Manual de métodos de análise microbiológica de alimentos e água. 4. ed. São Paulo: Livraria Varela, 2010. 632p.

SILVA, J.G.; ABREU, L.R.; RESPLANDE, F.A. et al. [2011]. Características físico-químicas do queijo Minas artesanal da Canastra. Revista do Instituto de Laticínios Cândido Tostes, v.66, n.380, p.16-22, 2011. Disponível em:

$<$ http://www.revistadoilct.com.br/rilct/arti cle/view/164>. Acesso em: 07/12/2013.

SILVA, R.A.; BISMARA, P.A.; MOURA, R.B. et al. [2012]. Avaliação da microbiota bacteriana do queijo de coalho artesanal produzido na região Agreste do Estado de Pernambuco. Arquivo Brasileiro de Medicina Veterinária e Zootecnia, v.64, n.6, p.1732-1738, 2012. Disponível em: < http://www.scielo.br/pdf/abmvz/v64n6/44 .pdf>. Acesso em: 28/12/2013.

TEBALDI, V.M.R.; OLIVEIRA, T.L.C.; BOARI, C.A. et al. [2008]. Isolamento de coliformes, estafilococos e enterococos de leite cru provenientes de tanques de refrigeração por expansão comunitários: identificação, ação lipolítica e proteolítica. Ciência e Tecnologia de Alimentos, v.28, n.3, p.753-760, 2008. Disponível em: <http://www.scielo.br/pdf/cta/v28n3/a36v 28n3.pdf>. Acesso em: 13/02/2014.

VALLE, J.L.E.; CAMPOS, S.D.S.; YOTSUNAGI, K. et al. [2004]. Influência do teor de gordura nas propriedades funcionais do queijo tipo mozarela. Ciência e Tecnologia de Alimentos, v.24, n.4, p.669-673, 2004. Disponível em:

<http://www.scielo.br/pdf/cta/v24n4/a32v 24n4.pdf>. Acesso em 12/12/2013.

WOLD, J. P; JORGENSEN, K.; LUNDBY, F. [2002]. Nondestructive measurement of light-induced oxidation in dairy products by fluorescence spectroscopy and imaging. Journal of Dairy Science, v.85, n.7, p.1693-1704, $2002 . \quad$ Disponível em: <http://www.journalofdairyscience.org/ar ticle/S0022-0302(02)74242-2/abstract>. Acesso em: 15/03/2014.

YASMIN, A.; HUMA, N.; BUTT, M.S. et al. [2012]. Seasonal variation in milk vitamin contents available for processing in Punjab, Pakistan. Journal of the Saudi Society of Agricultural Sciences, v.11, n.2, p.99-105, 2012. Disponível em: <http://www.sciencedirect.com/science/a rticle/pii/S1658077X12000033>. Acesso em 12/04/2014. 